\title{
DOES A CONNECTION EXIST AMONG NATIONAL CULTURE, ALLIANCE STRATEGY, AND LEADING ICT FIRMS' PERFORMANCE?
}

\author{
Monika Golonka ${ }^{1}$, Robert Rzadca ${ }^{2}$ \\ ${ }^{1}$ Management Department, Kozminski University, Jagiellonska St.59, Warsaw, Poland \\ ${ }^{2}$ Business Strategy Department, Kozminski University, Jagiellonska St.59, Warsaw, Poland \\ E-mails: ${ }^{1}$ monikagolonka@kozminski.edu.pl (corresponding author); \\ ${ }^{2}$ rzadca@kozminski.edu.pl
}

Received 12 February 2012; accepted 17 September 2012

\begin{abstract}
In this paper we explore links among firms' performance, firms' alliance strategies, and national culture in the context of the global information and communication technologies (ICT) industry. Currently, partnering is the one of the most effective ways to access a broad set of resources. In the ICT industry, we can observe a significant number of alliances, networks, and mergers and acquisitions. The contribution of this paper is to investigate how a contextual factor - namely, national culture - influences the alliance portfolio formation and a firm's performance. We also aim to contribute to the issue of alliance portfolio formation. First, the concepts of alliance portfolio and culture as an explanatory factor are elaborated upon and their relevance to the study discussed. Second, using a sample of 30 ICT leaders and 10,247 of their alliances, we explore the effect of alliance strategy on firms' performance as well as the connections among culture, firms' performance, and alliance strategy. The study confirms that, in a global ICT industry (i.e., the most dynamically changing and riskiest environment), weak alliances may increase a firm's performance more than strong, traditional strategic alliances. Culture may be used as one of the explanatory factors affecting firms' performance as well as firms' alliance strategies.
\end{abstract}

Keywords: Global strategy, alliance portfolio, strength of ties, exploration and exploitation, ICT industry, cultural dimensions.

Reference to this paper should be made as follows: Golonka, M.; Rzadca, R. 2013. Does a connection exist among national culture, alliance strategy, and leading ICT firms' performance?, Journal of Business Economics and Management 14(Supplement 1): S395-S412.

JEL Classification: L20.

\section{Introduction}

In recent years, management literature has focused on inter-firm relationships, alliances, both quality and quantity of alliances, firms' alliance portfolios, and inter-firm networks. Currently, particularly in global industries, forming alliances with potential competitors

This article has been corrected since first published. Please see the statement of correct (https://doi.org/10.3846/16111699.2017.1275283). 
is an increasingly common way to protect a firm's competitive position. Many existing studies focus on creating a competitive advantage at the global scale using strategic partnerships or joint ventures (e.g., Kogut 1988; Gomes-Casseres 1994; Yan 1998). Some studies have examined the impact of alliance portfolio on firms' performance (e.g., Powell et al. 1999, Lee et al. 2001, Lavie 2007). We argue that the types of alliances may have essential meaning in information and communication technologies (ICT) firms' performance. According to March (1991) and Dussauge et al. (2000), alliance strategy is associated with the quality of relationships. The character of alliances, in turn, influences the acquisition of resources and skills from partners.

Most recently, some researchers have called for a holistic approach to firms' alliance strategies, considering organizational, and environmental factors in understanding the performance implications of alliances (e.g., Yamakawa et al. 2011; Rowley et al. 2000). Although previous studies have provided advanced understanding of links between alliances and firms' performance, many gaps remain in the research on certain alliance strategies performed by firms, especially in the contextual perspective. In the face of increasing competition from emerging economies, addressing questions of differences between firms' alliance strategies has become essential (Peng 2009). What is the effect of alliance strategy on firms' performance in one of the most dynamically changing environments-namely, the ICT industry? Is there any link between contextual factors (i.e., the firm's culture of origin) and the firm's alliance strategy and market performance?

The alliance and alliance portfolio research offers only limited insights into this phenomenon. In addition, most studies in this area have been conducted on the basis of firms from one country of origin, mainly from the US. Recently, some strategic management researchers have started considering the impact of cultures on inter-firm alliance creation; in the international management field, a large number of studies exist on the effect of cultural factors on direct strategic alliances, partnering strategies for joint ventures, and cross-cultural contexts. Studies show that national culture influences firms' models of organization (Hofstede 2005), internal processes and decision-making processes (Rugman, Collinson 2009), strategic choices (Kogut, Singh 1988), performance (Ghamewat 2001) and members' values (Chang et al. 2003). Understanding the role of contextual factors like national culture in alliance portfolio formation and its influence on firms' performance in the context of global competition seems to be particularly important in the fast growing and rapidly changing ICT industry.

The purpose of this paper is to contribute to the understanding of the links among a firm's alliance strategy, market performance, and contextual factors (i.e., cultures) based on leading global ICT firms. Although many conceptual studies have examined these issues, the number of empirical verifications of proposed concepts is extremely limited.

In the first section of the paper, we discuss the fundamental elements of alliance strategy, different approaches to alliances, and results of existing studies in the context of the ICT industry. We then discuss the cultural context of firms' strategy and organization as well as its relevance to alliance strategy and firms' performance. Based on these discussions, we propose a model for the research and empirically test the hypotheses of the study. In the final sections, we present conclusions and a discussion of the research results in addition to study limitations and future research directions. 


\section{Alliance strategy and firms' performance}

\subsection{Alliance portfolio}

Establishing and exploiting alliances between firms takes many forms as the spectrum of ties included in the term alliance is quite broad. We use term the alliance as a general term that has been deeply established in the literature, covering the entire spectrum of inter-firm ties, from for example license agreements to capital joint ventures (Contractor, Lorange 1988). In recent studies, much attention has been paid to networks, alliances, and alliance portfolios. An alliance is seen as a direct tie connecting two firms. In the inter-firm networks, multiple alliances can exist from one node to another. An alliance portfolio refers to the egocentric network of a firm's collection of direct alliances with partners (Wasserman, Faust 1994; Lavie 2007). In this study we focus on alliance portfolio and the focal (egocentric) firm's alliance strategy (Lavie 2007).

\subsection{Alliance strategy and firm performance in the context of the ICT Industry}

Much evidence exists that firms compete successfully using alliances, especially in the dynamically changing global environment, including high-technology industries (Hagedoorn 1993; Rothaermel, Deeds 2004). Prior research has provided evidence for a strong positive connection between alliance portfolio and firm performance (e.g., Lavie 2007; Rothaermel, Deeds 2004). Previous studies have indicated that strategic alliance groups lead to asymmetric access to resources in the industry, thereby affecting firms' behavior and performance (Granovetter 1985; Burt 1992; Nohria 1991). Farina (2008) developed and tested the idea of the impact of network structure and network embeddedness on firm performance. He treated the network as the external resources that a company can use in strategic maneuvers in order to increase its efficiency. Other studies have shown that the ties in the network may become a potential source of external resources for the company (Nohira 1991), while their effectiveness depends on the network structure (Burt 1992) as well as the firm's internal capabilities (McEvily, Zaheer 1999). Hallikas et al. (2008) examined the evolution of network structure in telecommunications, IT, and media industries in the context of alliances and discovered that the best performing firms use both internal R\&D and external relations to acquire the necessary resources. Shipilov (2006), examining banking chain studies, proved that banks participate in partnership with other banks to get access to their resources (e.g., information on public procurement, offers, occasions). Vivio (2004) analyzed five IT firms from developing countries to demonstrate that the firms were able to create a competitive advantage globally, creating alliances and using external resources. In addition, Lavie (2007) argued that alliances with well-equipped partners (e.g., technology, finances, marketing, human resources) contribute to the growth of a company and its market performance.

However, studies have also demonstrated that the multiplicity of alliances is not the only important factor. The quality, purpose, and scope of relationships can be even more important (Gulati 1998, 2007). In the literature, the purpose and scope of inter-firm alliances is associated with the terms exploitative and explorative strategy, often reflective of the different types of knowledge being transferred in the alliances (Rothaermel, Deeds 2006). However, the literature uses exploration and exploitation for different meanings. Thus, we propose our definitions for this study. Types of firms' strategies 
accomplished within alliances with other companies are related to the strength of ties (March 1991; Dussauge et al. 2000, 2004 Peng 2009). Based on this classification, we use explorative strategy to reflect weak types of alliances and exploitative strategy to reflect strong alliances. According to Rothaermel, Deeds (2006: 434), firms often use an explorative strategy to access the newest knowledge required to move from a commercially feasible technology to the marketable products, although firms can build strong alliances in the product development process. The greater the uncertainty in the market environment and the stronger the need for innovation to survive, the more possible it is for that firm to decide on an explorative strategy (March 1991). This strategy allows for the exploration of new, uncertain, riskier areas, testing rules and strategic choices. According to Koza and Levin (1998), the explorative strategy is usually not associated with a relationship involving joint capital. A weak tie can take the form of, for example, licensing agreements, marketing agreements, joint delivery of projects, and solutions (often used to gain access to the latest information and are connected with the possibility of "penetrating" the network). The choice of partners in the case of weak alliances is often addressed by the possibility of access to different areas of the network rather than specific partners (Granovetter 1985).

Meanwhile, an exploitative strategy requires a deeper understanding of the area in which it is applied. This strategy is used when more specialized knowledge is necessary. This type of strategy is based on strong alliances (Krackhardt 1992), social capital (Bordieu 1986), and a high level of network embeddedness (Granovetter 1985). The purpose of this type of strategy is to strengthen existing alliances to build a new one-namely, a direct partnership. In this case, only interested strategic partners (allies) who are valuable are directly connected with real, measurable commitment. This strategy is characterized by a greater number of contracts with the same partner, longer relationships, and frequent cooperation (Contractor, Lorange 1988; Krackhardt 1992).

The literature on alliance strategy indicates that both types of alliances-weak and strong - may provide adequate benefits. A company may have in its portfolio various types of alliances. The choice of alliances types is often related to the environment in which the company operates (Rowley et al. 2000). Lant et al. (1992) argue that, in more uncertain, changing and growing sectors, where firms are afraid to invest in uncertain future developments, firms are more likely to decide on an explorative strategy, seeking out and testing new options. The results of some studies have highlighted the negative impact of strong alliances on a firm's performance in industries with higher dynamics of changes (Rowley et al. 2000).

Phenomena related to the global strategy and alliance portfolio formation are clearly evident in the ICT industry. ICT, which includes firms providing both services and products, is one of the fastest-growing sectors worldwide (Fine 1998). Moreover, technological development and the convergence of services have led to huge number of alliances, mergers, acquisitions, strategic partnerships, and groups of alliances (Varun, Khawaja 2003). The ICT industry is a highly knowledge and technology-intense sector, wherein firms constantly face changes related to issues such as digital convergence, convergence of products and services, and increasing competition of companies from emerging markets (Varun, Khawaja 2003; Sengupta et al. 2006). In response to the 
increasingly rapid changes in the environment, companies create an increasing number of weak alliances. The ICT industry is defined as a growing area created between the IT and telecommunications industry, where leading global players like Google, Apple, Microsoft, and Samsung as well as global vendors like Oracle, IBM, and Huawei try to create competitive advantages (TBR, Ovum, and Gartner, 2007-2010).

The total growth of the number of alliances in all focal firms' alliance portfolios* of leading global ICT firms reached 34 percent from 2000 to $2009^{1}$. The total share of all weak alliances in all focal firms' alliance portfolios was 70.2 percent, and the share of strong alliances was only 29.8 percent. These data indicate that weak alliances are currently widely chosen by ICT firms.

One of the examples of firms using effectively weak and strong alliances in a global ICT industry is Chinese Huawei Technologies. Huawei's global expansion is undoubtedly connected with building numerous alliances (Low 2007). Weak alliances with companies present on foreign markets primarily allowed the firm to sell products and services on these markets (with partners from, inter alia, Germany, Russia, Sweden, the US, Israel, the UK, Canada, Australia, India, Venezuela, France, and several African countries). Thanks to these relationships, Huawei was able to not only enter new markets, but also establish relationships with new customers that are also seen as key resources (Gulati 2007). Weak alliances allowed for experimenting with new markets, business models, new customers, and selling solutions with business partners - the main aim of explorative strategy, as previously described. Strong alliances allowed for conducting joint research and development projects (e.g., in cooperation with Grameenphone, WTIA, Avici Systems Inc.), and capital joint ventures (with NEC Corp., Nortel Networks). These alliances required establishing longer-term cooperation, often involving capital investments; thus, they were more formalized and structured, had a fixed scope and purpose, and provided dedicated management - all characteristics of an exploitative strategy.

Taken together, we argue that, in the global ICT industry, the explorative strategy is positively associated with firms' market performance in the short term. In the ICT industry, rules change quickly, time to market has an essential meaning, and firms are forced to experiment with new products, solutions, and even business models (Golonka 2012). In such an environment, an exploitative strategy related to the traditional (i.e., strong), more costly, longer-term alliances with a fixed scope and purpose, often involving invested capital, may have a negative impact on a focal firm's performance in the short term. In order to verify the connection between alliance strategy and firm performance in the ICT industry, we propose Hypotheses 1a and 1b:

H1a: Explorative strategy, connected with the weak alliances ratio in an ICT firm's alliance portfolio, is positively associated with the focal firm's market performance.

H1b: Exploitative strategy, connected with the strong alliances ratio in an ICT firm's alliance portfolio, is negatively associated with the focal firm's market performance.

\footnotetext{
${ }^{1}$ Based on our research sample; see the Data and methodology chapter.
} 


\section{National culture, organizational model, and alliance strategy}

The main research traditions originated and fully grew in well-developed economies, particularly the US economy. As research expanded into other less advanced and emerging economies, culture played an increasingly important role in explaining firms' strategies. The consideration of the strategic choices at the global scale is insufficient without considering the institutional - including cultural factors - approach (Meyer et al. 2009; Yamakawa et al. 2008). According to Peng (2009), a company's success at the global scale as well as decision-makers' choices depend to a certain degree on cultural factors.

Although some researchers believe that the processes of globalization and technological changes may determine change in certain values in different cultures (Inglehart, Baker 2000; Nieves et al. 2006), according to Hofstede (2005) and also Minkov (2010), cultural changes require a long-term horizon or extremely dramatic external events. Globalization processes do not change the values and beliefs across countries: Strong traditional values, such as group solidarity, interpersonal harmony, and paternalism, can coexist with modern values of individual achievement and competition (Chang et al. 2003; Zhang et al. 2003). It is worth noting that the top-down effects on cultural change are also moderated by culture itself (Inglehart, Baker 2000).

Much evidence exists on the influence of national culture on a firm's international investments (Kogut, Singh 1988), decision processes (Rugman, Collinson 2009), leadership values (Ralston et al. 1997), employee values (Chang et al. 2003), inter-firm cooperation (Child, Faulkner 1998), and performance (Ghamewat 2001). National culture affects the organizational model, decision-making processes, people's values and perceptions, and organizational governance as well as controlling information and its use from a centralized to a decentralized perspective (Davenport 1997, Hofstede 2005). Culture is one of the crucial factors of the organizational environment, influencing the organizational structure (complexity, formalization, centralization - Robbins 1987), decision making and implicit models in people's minds in terms of what an organization should be (Varsakelis, Kessapidou 2002: 269).

The cultural dimensions approach proposed by Hofstede $(1991,2005)$ is the most influential classification of cultures found in the literature (Peng 2009; Rugman, Collinson 2009). Hofstede proposed the five-dimension model, which includes individualism/collectivism, masculinity/femininity, uncertainty avoidance, power distance, and long-term orientation. Sondergaard (1994) showed that the differences predicted by Hofstede's dimensions were largely confirmed. Researchers (e.g., Hébert, Link 1989; Nadeljkovic 2011) argue that two dimensions of Hofstede's model play the most significant role in the explanation of firms' strategies and organization: uncertainty avoidance and power distance. Most authors in the organizational theory field recognize three major components of organizational structure: complexity, formalization, and centralization (John, Martin 1984; Robbins 1987). Schein (1988) further identified three dimensions: the hierarchical dimension, functional dimension, and dimension of inclusion and centrality. People's perceptions of how organizational structure works play an important role in organizational structuring and the effectiveness of structures (Harrington 1991). Or- 
ganizational structure is a "manifestation of cultural values" (Berger, Luckmann 1967, Gibson 1994).

According to Hofstede (2005), who incorporated Mintzberg's (1983) organizational models, much evidence exists to propose the existence of the correlation between a country's position in the power distance-uncertainty avoidance (PDI-UAI) diagram and models of organizations implicitly present in the minds of people from these cultures. The proposed models affect the way in which problems are tackled and how things work organizationally. The metaphorical models describe the nature of organizations: a pyramid of people, a village market, a well-oiled machine, and a family (Hofstede 2005).

The village market type of organization, characterized by low power distance and weak uncertainty avoidance, has a preference for decentralized authority and often an ad-hoc, unstructured workflow. Information is shared across organizational or functional areas and is defined and interpreted by organizational groups according to the situational demands. Such organizations are usually flexible in their response to the environmental conditions and are characteristic for countries like the US, the UK, Australia, Canada, Sweden, and Norway.

The family model of organization, with a large power distance and weak uncertainty avoidance, is typical for organizations from countries like China, India, and Singapore. Its organizational structure and its decision-making processes and policies are paternalistic, with a preference for autocratic, centralized authority. Yet the business processes are still not framed with a lot of rules and formalization.

The pyramid of people type of organization is characterized by a large power distance and strong uncertainty avoidance, as in France, Japan, Korea, and Taiwan. This type of organization is structured and formalized. It centralizes authority and prefers a structured, hierarchical workflow. In such a model of organization, decision-making processes are slow because of the hierarchy and bureaucracy.

Finally, the well-oiled machine organization, with its low power distance and strong uncertainty avoidance (common in Germany, Austria, and Finland), usually does rely on rules and procedures to structure business processes to create a functionally efficient organization.

Although corporate culture and the model of the organization do not depend on culture alone, strong evidence suggests that the dimensions of power distance and uncertainty avoidance influence the structures and functions of organizations. The national culture influences not only the organizational model preferred by the company, but also the strategy formulation, as strategies are chosen on the basis of assumptions regarding the environment and relationships among people (Schneider 1989).

A huge amount of research has been conducted since the 1960s on the strategy-structure-performance issue. For example, Burns and Stalker (1961) argued that, in dynamic economic sectors, firms with less hierarchy and fewer formal structures are more effective. Organizational centralization negatively affects firms' knowledge performance (Pertusa-Ortega et al. 2009). Results of Nahm's et al. (2001) study indicated that the 
nature of formalization, the number of layers in the hierarchy, and the level of horizontal integration have significant, direct, and positive effects on the locus of decision making and level of communication. Dess and Lumpkin (2005) discussed five dimensions of corporate entrepreneurship, including autonomy, innovativeness, competitive aggressiveness, and risk-taking, and its influence on firm's performance. The results also support previous research in this field.

In rapidly growing market sectors, time to market, complexity of solutions, and flexibility are major success factors (Varun, Khawaja 2003). For high-performing organizations, it is necessary to possess the capabilities of adaptive ability (abilities in flexible integrating, building, reconfiguring resources) and innovative ability (innovative behaviors and processes in developing new products and solutions faster than competitors) (Wang, Ahmed 2007). We argue that, in organizations characterized by a high level of formalization, centralization, and multilevel hierarchy where individuals have a relatively low valuation of autonomy (e.g., pyramid of people), the market performance will be lower, and there will be a tendency to form traditional, formalized, strong alliances, related to the exploitative strategy. Meanwhile, weak alliances, often based on ad-hoc projects and sometimes even on informal agreements, may be created in organizations characterized by a low level of formalization, decentralized decision making, and flatter hierarchies (e.g., family, village market). Thus, Hypotheses 2 and 3 have been formulated as follows:

H2: ICT firms originating from cultures with a tendency for more structured, hierarchical, and formal organizations have a lower market performance.

H3: ICT firms originating from cultures with a tendency for more structured, hierarchical, and formal organizations have a lower explorative alliance ratio in their alliance portfolios.

Figure 1 depicts our research model and summarizes the hypotheses.

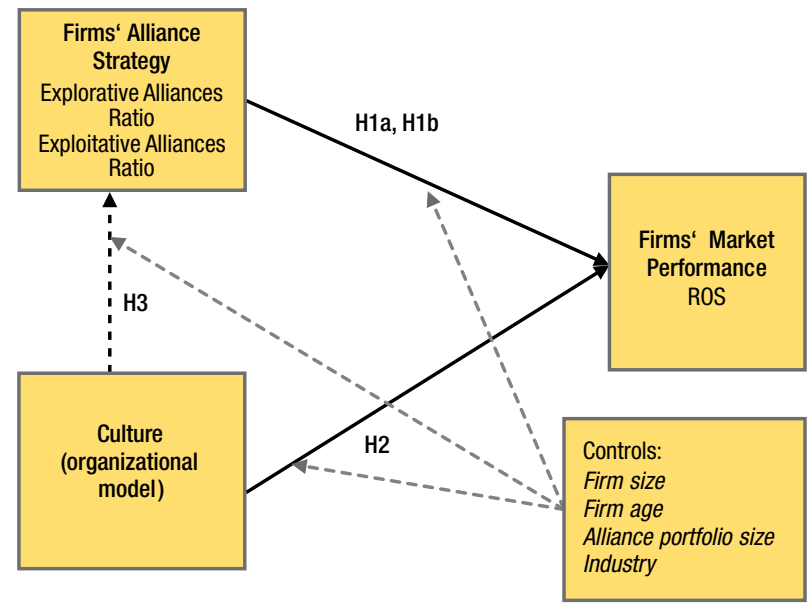

Fig. 1. Theoretical framework 


\section{Data and methodology}

We analyzed all leading ICT global vendors based on the SIC code (four digit) and industry reports (TBR, Ovum, and Gartner 2007-2010), offerings in their portfolios products, services and solutions, and global operations. In addition, we asked industry experts for confirmation of the list of selected firms to this research. In order to ensure complete coverage of alliances, we created the database of ties, based on the SDC Platinum Database as well as an analysis of press and corporate websites. Following Anand and Khana (2000) and Lavie (2007), we compiled records of alliances formed by each focal firm; we then complemented and corrected the data by searching publicly announced alliances in press releases and corporate websites of focal firms. More than 20,000 alliances were identified for all focal firms. After cleaning the data and removing terminated alliances, the final sample included the 30 most significant global focal firms in the ICT industry that offer in their business portfolios solutions including products and services dedicated to telecommunication operators. Firms' headquarters are located in the US, Europe, and Asia and they have in total 10,247, alliances, including 7,258 unique allies in focal firms' portfolios.

For each focal firm we coded the SIC code, firm size, country of origin, and firm age; we also compiled records of alliances formed by each firm. For each alliance we coded the type of tie, date of announcement, status in each year, and number of participating partners. We extracted institutions' data from Hofstede's cultural dimensions model (Hofstede's website 2009) and organizational model. According to the European Commission of Information Society and Media (The world's economies depend on Information \& Communication Technologies (ICT), 2010), a significant difference exists in the meaning and contribution of ICT to productivity before and after 2000. Prior to 2000, the US played a primary role in shaping the global ICT industry. After 2000, the EU as well as the Asia and Pacific region became increasingly relevant on the global scale. Thus, in order to ensure the most recent and reliable data, our research covers a 10-year time period, from 2000 until 2009, yet tracked historical alliances back to the year 1995 in order to ensure the coverage of active alliances (a 5-year window is a conventional assumption in alliance network research) (Lavie 2007). For our OLS analysis year 2007 has been selected as the last one before global financial crisis.

\section{Measures}

\section{Firm Performance}

We used focal firm market performance as our dependent variable in regression Models 1 and 2. We decided to use firms' short-term performance measured by return on sales (ROS) to avoid the inherent limitations of return on assets (ROA). According to Lavie (2007) as well as Brush et al. (2000), ROA often discounts firms' intangible assets, which are potentially pervasive in the case of ICT firms (in our sample, Tobin's $q$ reached 1.8, indicating a high proportion of such assets). ROA is commonly used as a market performance in the literature, but might be not be adequate in alliance strategies given the possibility of intervening and confounding firm-level factors that are significant for direct benefits from alliances. In our case, ROS is a more reliable measure of 
market performance, especially for firms with varying sizes (Leech, Leahy 1991); it also takes into account that ICT is a fast growing market sector wherein sales has a crucial meaning for competitive advantage development by selling new projects and solutions to existing and new customers. We calculated the ROS for each focal firm in each firm year based on financial reports from the financial database.

\section{Explorative Alliances Ratio and Exploitative Alliances Ratio}

Although alliances between firms can take many forms, including both strong and weak alliances, following Nohira (1991), and Lavie, Rosenkopf (2006), in this study we identified and coded alliances for each company's portfolio and grouped them into two categories. We used Lavie and Rosenkopf's (2006) method as they provide a scheme for coding alliances based on the announced purpose of each alliance. Strong alliances related to the exploitative strategy (Granovetter 1985; Krackhardt 1992) included capital alliances, joint ventures, production joint ventures, and R\&D alliances, assuming also multiple agreements with the same partner as strong alliances. Meanwhile, weak alliances related to the explorative strategy (Powell 1990) included marketing agreements, license agreements, selling and service agreements, and the joint delivery of projects. In order to measure the shares of both types of alliances, we used a ratio-simply, the total number of a certain type of alliances over the total number of alliances in each focal firm's alliance portfolio.

Explorative Alliances Ratio = (Total number of weak alliances $x 100 \%) /$ Total number of alliances in focal firm's alliance portfolio.

Exploitative Alliances Ratio $=($ Total number of strong alliances $x 100 \%) /$ Total number of alliances in focal firm's alliance portfolio.

\section{Culture: national culture and organizational model}

In order to cover culture as an explanatory factor in this study, we used Hofstede's (2005) PDI-UAI cultural dimension classification, which incorporated Mintzberg's (1983) typology. Three models of firms were identified - namely, pyramid of people, family, and village market. We coded the type of organization for each focal firm based on the firm's organizational structure and organizational model construct (Hofstede 2005, Mintzberg 1983). We had only one "well-oiled machine" firm in our sample; thus, we excluded this model from our analysis. In addition, as the formal organizational structure is primarily reflected in the organizational chart (Harrington 1991), and according to Damanpour (1991) the hierarchical level of organizational structure refers to the number of levels in the firm's hierarchy below the chief executive level, we identified organizational structure and its hierarchy level for each focal firm (based on corporate websites, reports and press analysis) and mapped the structure on Hofstede's PDI-UAI diagram in order to confirm the models used in the study.

\section{Control variables}

In order to have accurate results for hypothesis verification, we used all significant control variables that might impact the results of the analysis-namely, firm size, firm age, alliance portfolio size, and industry (Lavie 2007). The size of the firm is commonly 
used in empirical estimations based on the assumption that it affects profitability due to economies of scale. We focused on leading (in terms of size, significance due to the industry reports, and SIC qualification) global ICT firms. However, we involved firm size as a control variable in the regression analysis. Firm size is measured as a logarithm of the number of the focal firm's employees. In this study, firm-level control variables also included firm age (taking into account that well-established firms from mature economies were usually incorporated earlier than global players from emerging markets), which was measured by subtracting the year the firm was incorporated from the alliance contraction year to determine the numbers of year the firm had been in operation. We also controlled alliance portfolio size by calculating the logarithm of the total number of ties in the focal firm's alliance portfolio. Finally, we controlled the inter-industry variation by focusing on the ICT industry.

\section{Analysis}

We used ordinary least squares (OLS) regression analysis to analyze our data. The firm was considered the operational unit of analysis. There are three models in our analysis. We provided the explanatory variables for our regression analysis separately to avoid the possible threat of multicollinearity in the first model due to an observed moderate correlation between our two explanatory variables (Table $1, \mathrm{r}=0.35$ ). First, we added control variables and one independent variable (firm type) to our regression model. Second, we added a second independent variable (Explorative alliances ratio). Finally, we formulated an additional model with Explorative alliances ratio as a dependent variable to test Hypothesis H3. The observed modest overall level of correlation indicates that no threat of multicollinearity exists in this study (Varaskelis, Kessapidou 2002). In addition, the regression models reached good explanatory power. Missing values were treated with case deletion. In addition, we used the test of means as well as the U-Mann Whitney non-parametric test to analyze the differences between groups (weak and strong alliances ratios) for each organizational model.

\section{Results}

Table 1 presents detailed descriptive statistics, including the means, standard deviations, and correlations matrices; Table 2 presents results of OLS regression analysis. Hypothesis 1 investigates the influence of focal firms' alliance portfolios on firms' performance. Consistent with Hypothesis 1, a firm's market performance measured by ROS is influenced by the alliance strategy. The weak alliances ratio is positively correlated with a firm's market performance $(\beta=0.40, p<0.01)$, indicating that ROS might be increased by weak alliances (e.g., sales and marketing-oriented alliances) as opposed to strong alliances (e.g., joint R\&D projects, production or manufacturing ventures) in the global ICT industry $(\beta=-0.40, p<0.01)$. The results strongly support Hypothesis $1 \mathrm{a}$ and Hypothesis $1 \mathrm{~b}$. 
M. Golonka, R. Rzadca. Does a connection exist among national culture, alliance strategy, and leading ...

Table 1. Detailed descriptive statistics and correlation matrices

\begin{tabular}{clccccccc}
\hline No. & \multicolumn{1}{c}{ Variable } & Mean & Std Dev. & 1 & 2 & 3 & 4 & 5 \\
\hline 1 & Firm performance - ROS & 6.22 & 16.84 & & & & & \\
\hline 2 & Firm size & 4.83 & 0.45 & 0.13 & & & & \\
\hline 3 & Firm age & 38.55 & 33.13 & -0.30 & 0.37 & & & \\
\hline 4 & Portfolio size & 1.87 & 0.78 & -0.06 & 0.67 & 0.54 & & \\
\hline 5 & Explorative Alliances Ratio & 65.18 & 19.65 & 0.50 & 0.02 & 0.05 & -0.07 & \\
\hline 6 & $\begin{array}{l}\text { Culture } \\
\text { (organizational model) }\end{array}$ & 1.96 & 1.22 & -0.32 & 0.24 & -0.06 & 0.00 & -0.35 \\
\hline $\mathrm{N}=30$ & & & & & & & & \\
\hline
\end{tabular}

Table 2. Results of OLS regression analysis for Firm's market performance

\begin{tabular}{lcc}
\hline \multicolumn{1}{c}{ Variables } & Model 1 & Model 2 \\
\hline Firm age & $-0.43(-2.33)^{*}$ & $-0.47(-2.77)^{*}$ \\
\hline Firm size & $0.56(2.52)^{*}$ & $0.43(2.06)^{*}$ \\
\hline Alliance portfolio size & $-0.20(-0.97)$ & $-0.07(-0.32)$ \\
\hline & Main variables & \\
\hline Culture (organizational model) & $-0.49(-2.97)^{* * *}$ & $-0.32(-1.96)\left(^{*}\right)$ \\
\hline Explorative Alliances Ratio & & $0.40(2.54)^{* *}$ \\
\hline Exploitative Alliances Ratio & & $-0.40(2.54)^{* *}$ \\
\hline Number of observations & 29 & 29 \\
\hline Adjusted R2 & 0.38 & 0.41 \\
\hline F statistic & $3.96 * *$ & $5.15^{* * *}$ \\
\hline
\end{tabular}

Notes: t-Statistics are in parentheses. Dependent variable: Market performance. Missing values were treated with case deletion. ${ }^{*} \mathrm{p}<.05 ; * * \mathrm{p}<.01 ; * * * \mathrm{p}<.001$.

Hypothesis 2 examines the effect of culture on a firm's market performance. We reported that each firm's cultural model (UAI-PDI) related to the firm's organization and structure, ranging from lowest to highest hierarchy and formalization, is significantly correlated with the firm's market performance $(\beta=-0.49, p<0,001)$. Meanwhile, the degree of hierarchy and formalization characterizing the focal firm's model of organization is negatively associated with the firm's market performance. This result supports Hypothesis 2.

In support of Hypothesis 3, regression Model 3a and Model 3b (Table 3) indicate an effect of culture on alliance strategy; we can observe a statistically significant correlation between the firm's model and the weak alliances ratio $(\beta=-0.42, p<0.05)$. In other 
Table 3. Results of OLS regression analysis for Exploitative Alliance Ratio

\begin{tabular}{lcc}
\hline \multicolumn{1}{c}{ Variables } & Model 3a & Model 3b \\
\hline Firm age & Controls & $0.08(0.39)$ \\
\hline Firm size & $0.13(0.10)$ & $0.33(1.27)$ \\
\hline Portfolio size & $0.14(0.53)$ & $-0.33(-1.24)$ \\
\hline Culture (organizational model) & $0.23(-0.82)$ & $-0.42(2.23)^{*}$ \\
\hline Number of observations & Main variables & 30 \\
\hline Adjusted R2 & 30 & 0.43 \\
\hline F statistic & 0.11 & 1.46 \\
\hline
\end{tabular}

Notes: t-Statistics are in parentheses. Dependent variable: Explorative Alliances Ratio. ${ }^{*} \mathrm{p}<.05 ; * *$ $\mathrm{p}<.01 ; * * * \mathrm{p}<.001$.

words, the more formal, hierarchical, and structured type of organization, the lower ratio of weak alliances in the firm's alliance portfolio. The results support Hypothesis 3 ; however, this hypothesis requires further research as the significance of the correlation is below 0.05 .

In addition, we found that the pyramid of people model is characterized by the largest share of strong alliances in a firm's alliance portfolio (49\%). The family has the largest share of weak alliances $(77 \%)$ whereas a greater-than-average share of strong alliances is typical for the village market (69.6\%). Figure 2 presents the share of weak and strong alliances share in all focal firms' alliance portfolios.

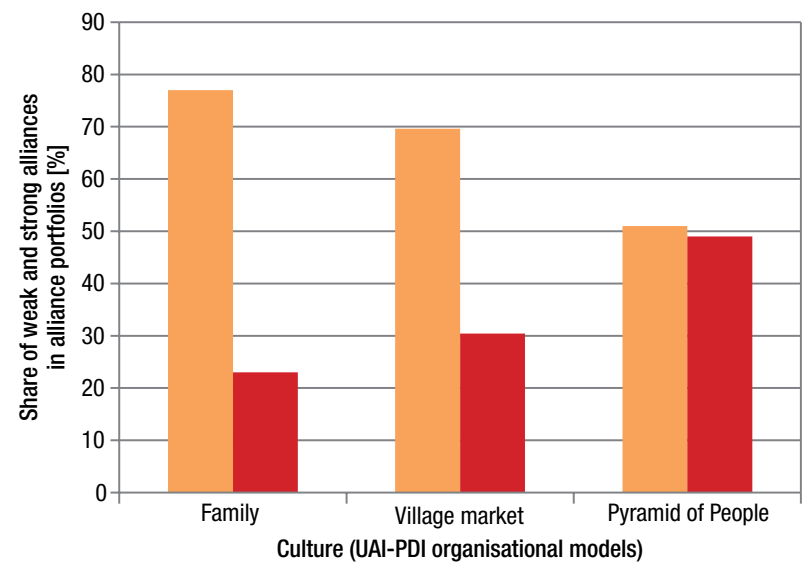

Fig. 2. Share of explorative and exploitative alliances in the firms' alliance portfolios 


\section{Conclusions}

In this study, we discussed the problem of alliance strategy related to weak and strong alliances as well as one of the contextual factors affecting firms' alliance strategy and firms' performance - namely, culture. We tried to show the connections among culture, firms' performance, and firms' alliance strategies. First, we analyzed the link between alliance strategy and firms' performance. Second, we analyzed connections between culture and firms' performance. Finally, we analyzed the link between culture and firms' alliance strategy.

Our findings seem to suggest that weak alliances in the dynamically changing, knowledge- and technology-intense ICT industry dominate strong alliances. The explorative strategy connected with weak alliances may be more effective in the short term and may increase firms' ROS. Previous studies have shown that, in certain environments, strong alliances can affect a firm's performance, also measured as ROA (e.g., Lant et al. 1992). We noticed that the share of strong alliances in firm's alliance portfolios was negatively correlated with firms' market performance in our sample. The exploitative strategy, based on strong alliances in the described environment, might have a negative impact on firms' performance for several reasons. As factors such as time to market, complexity of solutions, risk sharing, and flexibility have become extremely important, forming weak alliances allows firms to gain additional resources (including relationships with customers), enter new markets, and test new options much faster and less expensively than traditional, structured, formalized, strong alliances requiring dedicated management. This interpretation resonates with Rowley et al.'s (2000) finding that alliance strategy and its impact on firms' performance is embedded in an industry context; in highly changing industries, weak alliances may be a more effective way to improve firms' performance than strong alliances.

Our results also seem to support the contextual approach proposed by Yamakawa et al. (2011) and Rowley et al. (2000), expanding the industry-level factors to a wider perspective and considering culture as a significant contextual dimension. On the global scale, the "rules of the game" as applicable in different parts of the world are significant. These rules are both formal and non-formal and include culture, ethics, and standards in different countries. These rules significantly affect business development, competition, and - above all - firms' performance as well as their formation of alliances, relationships, and agreements among partners from different cultures.

We also found that the explorative strategy is characteristic for Asian ICT firms characterized by the "family" model (especially Indian firms, having more than $90 \%$ of weak alliances in their alliance portfolios), as well as for firms from some mature economies, such as the US, corresponding with the "village market" model (less significant meaning of hierarchy and rules; demands of the situation determine decisions and processes). The exploitative strategy is characteristic of the "pyramid of people" model common in such countries as France, Japan or Korea. Results of our research show that less formalized and structured organizations can benefit more with the explorative strategy.

Furthermore, our results emphasize the effect of the national culture and organizational model on internal processes, operations, strategy, and management methods (Rugman, 
Collinson 2009). Certain cultures are less formalized and structured; organizations originating from these cultures have a "natural" potential to become flexible and fast developing, forming weak alliances with many different market players. However, understanding the links among a firm's performance, culture-related factors, and alliances allows for managing the organizations in more knowingly and effective manner.

\section{Acknowledgements}

We would like to thank all anonymous reviewers for their helpful comments and suggestions that greatly improved this paper.

\section{Funding}

This work was supported by Polish Ministry of Science and Higher Education (grant number N N115 343838).

\section{References}

Anand, B.; Khanna, T. 2000. Do firms learn to create value? The case of alliances, Strategic Management Journal 21: 295-315.

http://dx.doi.org/10.1002/(SICI)1097-0266(200003)21:3<295::AID-SMJ91>3.0.CO;2-O

Berger, P. L.; Luckmann, T. 1967. The social construction of reality. New Yoork: Doubleday.

Bordieu, P. 1986. The forms of capital, in J. G. Richardson (Ed.). Handbook of theory and research for the sociology of education. New York: Greenwood Press, 241-258.

Brush, T. H.; Bromiley, P.; Hendrickx, M. 2000. The free cash flow hypothesis for sales growth and firm performance, Strategic Management Journal 21(4): 455-472.

http://dx.doi.org/10.1002/(SICI)1097-0266(200004)21:4<455::AID-SMJ83>3.0.CO;2-P

Burns, T.; Stalker, G. M. 1961. The management of innovation. London: Tavistock.

Burt, R. 1992. Structural Holes. Cambridge, MA: Harvard University Press.

Chang, W. C.; Wong, W. K.; Koh, J. B. K. 2003. Chinese values in Singapore: traditional and modern, Asian Journal of Social Psychology 6: 5-29.

http://dx.doi.org/10.1111/1467-839X.t01-1-00007

Child, J.; Faulkner, D. 1998. Strategies of cooperation: managing alliances, networks, and joint ventures. Oxford and New York: Oxford University Press.

Contractor, F. J.; Lorange, P. 1988. Cooperative strategies in international business. Lexington, MA.: Lexington Books.

Davenport, T. H. 1997. Information ecology: mastering the information and knowledge environment. Boston, MA: Harvard Business School Press.

Dess, G. G.; Lumpkin, G. T. 2005. The role of entrepreneurial orientation in stimulating effective corporate entrepreneurship, Academy of Management Executive 19: 147.

Dussauge, P.; Garrette, B.; Mitchell, W. 2000. Learning from competing partners: outcomes and durations of scale and link alliances in Europe, North America and Asia, Strategic Management Journal 21: 99-126.

http://dx.doi.org/10.1002/(SICI)1097-0266(200002)21:2<99::AID-SMJ80>3.0.CO;2-G

Farina, V. 2008. Network embeddedness, specialization choices and performance in investment banking industry. Raleigh: Lulu Enterprises. ISBN 978-88-6351-003-4.

Fine, C. 1998. Clockspeed. Cambridge: MIT Press. 
Ghamewat, P. 2001. Distance still maters. The hard reality of global expansion. Harvard Business Review 79(8): 137-140.

Golonka, M. 2012. Convergence, consolidation, coopetition - evolution of the ICT Industry, Przeglad Organizacji 3: 33-36.

Gibson, C. 1994. The impications of national culture for organization structure: an investigation of three perspectives, Advances in International Comparative Management 9: 3-38.

Gomes-Casseres, B. 1994. Group versus group: how alliance networks compete, Harvard Business Review, July-August: 4-11.

Granovetter, M. S. 1985. Economic action and social structure: the problem of embeddedness, American Journal of Sociology 91: 481-510. http://dx.doi.org/10.1086/228311

Gulati R, 1998. Alliances and networks, Strategic Management Journal 19: 293-317.

http://dx.doi.org/10.1002/(SICI)1097-0266(199804)19:4<293::AID-SMJ982>3.0.CO;2-M

Gulati, R. 2007. Managing network resources. Oxford: Oxford university Press

Hagedoorn, J. 1993. Understanding the rationale of strategic technology partnering: inter-organizational modes of cooperation and sectoral differences, Strategic Management Journal 14: 371-385.

Hamel, G.; Prahalad, C. K. 1989. Strategic intent, Harvard Business Review 67(3): 63-76.

Harrington, J. H. 1991. Business process improvement, New York: McGraw-Hill.

Hébert, R. F.; Link A.N. 1989. In search of the meaning of entrepreneurship, Small Business Economics 1: 39-49.

Hofstede, G. 2005 ( $1^{\text {st }}$ ed.1991). Cultures and organizations: software of the mind. 2nd ed. New York: McGraw Hill.

Inglehart, R.; Baker, W. 2000. Modernization, cultural change and the persistence of traditional values, American Sociological Review 65: 19-51. http://dx.doi.org/10.2307/2657288

John, G.; Martin J. 1984. Effects of organizational structure of marketing planning on credibility and utilization of plan output, Journal of Marketing Research 21: 70-80.

Kogut, B. 1988. Joint ventures: theoretical and empirical perspectives, Strategic Management Journal 9: 319-32. http://dx.doi.org/10.1002/smj.4250090403

Kogut, B.; Singh; H. 1988. The effect of national culture on the choice of entry mode, Journal of International Business Studies 19: 411-32. http://dx.doi.org/10.1057/palgrave.jibs.8490394

Koza, M. P.; Lewin, A.Y. 1998. The co-evolution of strategic alliances, Organization Science 9: 255-264. http://dx.doi.org/10.1287/orsc.9.3.255

Krackhardt, D. 1992. The strength of strong ties: the importance of philos in organizations', in N. Nohira, R. C. Eccles (Eds.). Networks and organizations: structure, form, and action. Boston, MA: Harvard Business School Press, 216-239.

Lant, T. K; Milliken, F.; Batra B. 1992. The role of managerial learning and interpretation in strategic persistence and reorientation: an empirical exploration, Strategic Management Journal 13(8): 585-608. http://dx.doi.org/10.1002/smj.4250130803

Lavie, D. 2007. Alliance portfolios and firm performance: a study of value creation and appropriation in the U.S. software industry, Strategic Management Journal 28: 1187-1212.

http://dx.doi.org/10.1002/smj.637

Lavie, D.; Rosenkopf, L. 2006. Balancing exploration and exploitation in alliance formation, Academy of Management Journal 49(4): 797-818. http://dx.doi.org/10.5465/AMJ.2006.22083085

Lee, C.; Lee, K.; Pennings, J. M. 2001. Internal capabilities, external networks, and performance: a study on technology-based ventures, Strategic Management Journal 22: 615-640.

http://dx.doi.org/10.1002/smj.181

Leech, D.; Leahy, J. 1991. Ownership structure, control type classifications and the performance of large British companies, The Economic Journal 101: 1418-1437.

http://dx.doi.org/10.2307/2234893 
Low, B. 2007. Huawei Technologies Corporation: from local dominance to global challenge?, Journal of Business \& Industrial Marketing 22(2): 138-144.

http://dx.doi.org/10.1108/08858620710730258

March, J. G. 1991. Exploration and exploitation in organizational learning, Organization Science 2(1): 71-87. http://dx.doi.org/10.1287/orsc.2.1.71

McEvily, B.; Zaheer, A. 1999. Bridging ties: a source of firm heterogeneity in competitive capabilities, Strategic Management Journal 20: 1133-1156.

http://dx.doi.org/10.1002/(SICI)1097-0266(199912)20:12<1133::AID-SMJ74>3.0.CO;2-7

Meyer, K. E.; Estrin, S.; Bhaumik, S.; Peng, M. W. 2009. Institutions, resources, and entry strategies in emerging economies, Strategic Management Journal 30(1): 61-80.

http://dx.doi.org/10.1086/226550

Minkov, M. 2010. Cultural differences in a globalizing world. Bingley: Emerald Group Publishing Limited.

Mintzberg, H. 1983. Structures in five. New York: Prentice Hall.

Nadeljkovic, M. 2011. Organizational Outcomes of the Fitting Between Organizational Structure and Hofstede's National Culture Indices, in I International Symposium Engineering Management And Competitiveness 2011 (EMC2011), June 24-25, 2011, Zrenjanin, Serbia [cited 20.02.2012] http://www.tfzr.uns.ac.rs/emc/emc2011/Files/A\%2001.pdf

Nahm, A. Y.; Vonderembse, M. A.; Koufteros, X. A. 2001. The impact of organizational structure on time-based manufacturing and plant performance, Journal of Operations Management 21: 281-306. http://dx.doi.org/10.1016/S0272-6963(02)00107-9

Nieves, R.; Mujtaba, B.; Pellet, P.; Cavico, P. 2006. Culture and universal professional values in global organizations: is there a divergence or convergence of cultural values?, Journal of Diversity Management 1(1): 31-38.

Nohira, N. 1991. Global Strategic Linkages and Industry Structure, Strategic Management Journal 12: 105-124.

Peng, M. W. 2009. Global strategy. 2nd ed. Cincinnati, OH: South-Western Cengage Learning.

Powell, W. 1990. Neither market nor hierarchy: network forms of organization, Research in Organizational Behavior 12: 295-336.

Powell, W.; Koput, K.; Smiss-Doerr, L.; Owen-Smith, J. 1999. Network position and firm performance: organizational returns to collaboration in the biotechnology industry, in Networks in and around organizations, Volume 16: Research in the sociology of organizations. Greenwich, CT: JAI Press, 129-159.

Pertusa-Ortega, E. M.; Zaragosa-Saez, P.; Claver-Cortes, E. 2009. Can formalization, complexity, and centralization influence knowledge performance?, Journal of Business Research 63(3): 310-320. http://dx.doi.org/10.1016/j.jbusres.2009.03.015

Ralston, D.; Holt, D.; Terpstra, R.; Kai-Cheng, Y. 1997. The impact of natural culture and economic ideology on managerial work values: a study of the United States, Russia, Japan, and China, Journal of International Business Studies 28: 177-207.

http://dx.doi.org/10.1057/palgrave.jibs. 8490097

Robbins, S.P. 1987. Organization theory: structure, design, and applications. Englwood Cliffs, New Jersey: Prentice-Hall.

Rothaermel, F. T; Deeds, D.L. 2006. Alliance type, alliance experience and alliance management capability in high-technology ventures, Journal of Business Venturing 21: 429-460.

http://dx.doi.org/10.1016/j.jbusvent.2005.02.006

Rowley, T.; Behrens, D.; Krackhard, D. 2000. Redundant governance structures: an analysis of structural and relational embeddedness in the steel and semiconductor industries, Strategic Management Journal 21: 369-386.

http://dx.doi.org/10.1002/(SICI)1097-0266(200003)21:3<369::AID-SMJ93>3.0.CO;2-M 
Rugman, A.; Collinson, S. 2009. International business. 5th ed. Pearson Education Limited. UK. Sengupta, S.; Mohr, J.; Slater, S. F. 2006. Strategic opportunities at the intersection of globalization, technology and lifestyle. Handbook of Business Strategy. Bradford: Emerald Group Publishing Limited.

Schein E. 1988. Organizational socialisation and the profession of management, Sloan Management Review 30: 53-65.

Shipilov, A. 2006. Network strategies and performance of Canadian investment banks, Academy of Management Journal 49(3): 590-604.. http://dx.doi.org/10.5465/AMJ.2006.21794676

Schneider, S. 1989. Strategy formulation: the impact of national culture, Organization Studies 10(2): 149-168. http://dx.doi.org/10.1177/017084068901000202

Sondergaard, M. 1994. Hofstede's consequences: a study of reviews, citations and replications. Organization Studies 15(3): 447.

Wang, C. L.; Ahmed, P. K. 2007. Dynamic capabilities: a review and research agenda, International Journal of Management Reviews 9(1): 31-51.

http://dx.doi.org/10.1111/j.1468-2370.2007.00201.x

Wasserman, S.; Faust, K. 1994. Social network analysis: methods and applications. New York: Cambridge University Press. http://dx.doi.org/10.1017/CBO9780511815478

Versakelis, N.; Kessapidou, S. 2002. The impact of national culture on international business performance: the case of foreign firms in Greece, European Business Review 14(4): 268-275.

Varun, G, Khawaja, S. 2003. The telecommunication industry revisited: the changing pattern of partnership, Communications of the ACM 46(7): 119-125. http://dx.doi.org/10.1145/792704.792709

Vivio, N. 2004. Alliance strategies: case studies. The GW Center for the Study of Globalization.

Yamakawa, Y.; Yang, H.; Lin, Z. 2011. Exploration versus exploitation in alliance portfolio: performance implications of organizational, strategic, and environmental fit, Elsevier, Research Policy 40: 287-296. http://dx.doi.org/10.1016/j.respol.2010.10.006

Yan, A. 1998. Structural stability and reconfiguration of international joint ventures, Journal of International Business Studies 29: 773-96. http://dx.doi.org/10.1057/palgrave.jibs.8490052

Zhang, X.; Zheng, X.; Wang, L. 2003. Comparative research on individual modernity of adolescents between town and countryside in China, Asian Journal of Social Psychology 6: 61-73. http://dx.doi.org/10.1111/1467-839X.t01-1-00010

European Commission of Information Society and Media: The world's economies depend on Information \& Communication Technologies (ICT) 2010. [Online], [cited 27 December 2011]. Available from Internet: http:// ec.europa.eu/information_society/newsroom/cf/dae/document.cfm?doc_id=205

Reports: TBR, 2007, 2008, 2009, Ovum, 2007, 2008, 2009 (www.ovum.com), Gartner: Global Telecommunications Market Take, December 2007, Telecom Contracts \&Vendors, 2007, OSS Observer - Global Telecom Software Market Analysis, 2008.

Monika GOLONKA. PhD, Assistant Professor, Kozminski University, Poland. She completed Executive MBA at Kozminski University, and has over 10 years of experience in the ICT industry as well as enterprise management. Her research interests include strategic, international and cross-cultural management.

Robert RZĄDCA. Professor, Negotiation Department, Kozminski University, Poland. Tutor, researcher, and entrepreneur in IT area. He is interested in strategic management and strategic negotiations as well as in public disputes. 